\title{
The Impact of Anaerobic Exercise Training on Some Selected Physical Fitness Components of U-17 Male Handballtrainees in Case of Injibara Town, Ethiopia
}

\author{
Awoke Tibebu Dessalegn Tilahun \\ College of Natural and Computational Science, Department of sport science, Debre Markos university \\ PO box 269 Debre Markos , Ethiopia
}

\begin{abstract}
The aim of this study was to examine the effect of anaerobic training on speed, agility and anaerobic power on U-17 Handball trainees. All off twenty six (26) Handball players who was the only Handball training project team at Injibara town with age U-17 were conveniently selected and participated voluntarily in the research. Among those half of them were randomly selected as EG which specially prepared anaerobic training was applied and the rest were CG. Weight and height averages of U-17 EG and CG were similar which is $56.92 \mathrm{Kg}$ and $57.77 \mathrm{Kg}$ in weight and $1.68 \mathrm{~m}$ and $1.71 \mathrm{~m}$ in height respectively. Before training, PT of two groups of thirteen (13) players (IAT and TT of agility tests, VJ and SLJ tests of anaerobic power tests and $10 \mathrm{~m} \mathrm{\&} \mathrm{40m}$ dash speed tests) were recorded. The anaerobic training were implemented on the EG twice a week, 35 to 40 min a day. Consequently after six weeks of anaerobic training, DT was taken in each parameter and a little improvement in each test results observed and training was continually given by increasing its intensity. After three months, posttest measurement on the same parameters was taken. The difference between the tests were analyzed statistically, with paired sample " $\mathrm{t}$ " test at $\mathrm{P}<0.05$ Consequently it was observed that anaerobic training implemented on junior level players brought about significant improvements between pre and post test results of agility, in which duration to complete IAT and TT was decreased by a mean difference of 0.381 seconds at $\mathrm{P}=0.001$ and 0.738 seconds at $\mathrm{P}=0.000$. Speed in which duration of $10 \mathrm{~m}$ and $40 \mathrm{~m}$ dash speed test result was decreased by a mean difference of .1262 seconds at $\mathrm{P}=.020$ and .1293 seconds at $\mathrm{P}=.010$ respectively.. And power, in which height and length of VJ and SLJ test result were increased by a mean difference of .06m at $\mathrm{P}=.000$ and $0.1161 \mathrm{~m}$ at $\mathrm{P}=0.000$ respectively. As result the investigator recommended that adding anaerobic training on their Handball training program helps to improve players speed, agility and power.
\end{abstract}

Keywords: agility, anaerobic exercise, performance enhancement, power, speed

DOI: $10.7176 /$ JTHS/46-01

Publication date: January $31^{\text {st }} 2020$

\section{INTRODUCTION}

According to Wallace \& Cardinale (1997), this sport requires a high level of physical condition in the relevant actions of the game like jumping, diving, blocking, running, sprint, and throwing. Handball is a very strenuous body-contact Olympic sport (Gorostiaga, et al., 2006)

Physical performance in Handball depends on various characteristics. Specifically, endurance, strength, speed, power and agility must all be well developed in order to achieve a high performance level in Handball. Handball match activities cover a range of intensities from low through moderate to high. One of the aims of training is to improve the ability to perform maximal and high-intensity exercise. Handball players must be able to perform anaerobic exercise (exercise at high-intensity, sprint, and develop high levels of power /force/ when kicking and tackling). Good levels of agility and coordination are also necessary and distinguish between elite and average players. Many sports require a combination of physical fitness components. For instance; Handball players should have the skill of shooting, passing and dribbling. A combination of short-duration strength, speed, and agility training is essential (Khodadad, A, 2008).

The fitness requirements for Handball depend on the level of performance. They vary also with age groups, between men and women, and at different stages of the playing season. Coaches, trainers and sports scientists acknowledge that preparation for competitive match-play calls for a systematic approach. This includes consideration of fitness levels of individual players as well as overall throughout the team. Attention to fitness profiles is relevant not just in the build-up towards key matches and tournaments but also throughout the competitive league season. To succeed based on results trainees need being testing selected parameters. These parameters have designed to predict performance capacity, taking in to account the player's current level of fitness and maturity (Peltola with Thomson \& Beavis, 1985). The test items may either be part of a comprehensive physiological assessment or be dedicated to performance in Handball. 


\section{Objectives of the Study}

General objective

The major aim of this study was to assess the effect of anaerobic training on selected skill related fitness components of U-17 Handball players.

Specific objectives

* To measure the effect of anaerobic training on agility of U-17 Handball players.

* To test the effect of anaerobic training on power of U-17 Handball players.

$\$$ To evaluate the effect of anaerobic training on speed of U-17 Handball trainees.

\section{MATERIALS AND METHODS}

\section{Description of the Study Area and Period}

The study was conducted in Injibara Town, south western part of the Amhara region and North western part of the county, Ethiopia. It is about $447 \mathrm{~km}$ away from the capital city of Ethiopia, Addis Ababa and $118 \mathrm{~km}$ from Bahir Dar, the capital city of the Amhara Regional state. Geographically, Injibara is found in $10^{\circ} 59^{\prime} \mathrm{N}$ and $36^{0} 55^{\prime} \mathrm{E}$ longitude. The highest and lowest altitude of Injibara is recorded to be $2540 \mathrm{~m}$.a.s.1 and $3000 \mathrm{~m}$.a.s.l respectively

\section{Study Design}

In this research pre, during and posttest patterned experimental study design on randomly selected $(\mathrm{n}=13)$ control group $(\mathrm{CG})$ and $(\mathrm{n}=13)$ experimental group (EG) was implemented. And a total of 26male Handball players, who took a two consecutive years of Handball training in Injibara town which organized and supported by Amhara Handball federation and trained by the investigator himself and one assistant coach, were voluntarily participated in the research. And regular yearly Handball training program was implemented on the control group (CG). While specially designed anaerobic training of 35 to 40 minutes twice a week for 12 consecutive weeks in addition to the regular training program was implemented on the experimental group

\section{Measurement Tools and Applications}

Medical Examination

Even if all the participants are already pre organized and selected based on their and family's interest and consensus as well as medical checkup early, while they join in to the team, the researcher prepared questionnaire for the identification of their current health status and additional consensus format and translated in to local language for ease of understanding and got confirmation to involve actively in this study and the researcher used following serious of skill related fitness tests and testified the hypothesis.

\section{Vertical jump test}

The purpose of this test was to measure the leg muscle power of subjects.

\section{Procedures and analysis}

The athlete stands side on to a wall and reaches up with the hand closest to the wall. Keeping the feet flat on the ground, the point of the fingertips is marked or recorded. This is called the standing reach height. The athlete then stands away from the wall, and leaps vertically as high as possible using both arms and legs to assist in projecting the body upwards. And jump height is usually recorded as distance score Getchell (1979).

\section{Standing Long Jump Test (Broad Jump)}

The standing long jump, also called the broad jump, is a common and easy to administer test of explosive leg power. The standing long jump was also once an event at the Olympic Games, and the purpose of this test is to measure the explosive power of the legs Getchell (1979).

\section{Procedure and analysis}

The athlete stands behind a line marked on the ground with feet slightly apart. A two foot take-off and landing is used, with swinging of the arms and bending of the knees to provide forward drive. The subject attempts to jump as far as possible, landing on both feet without falling backwards. Three attempts are allowed and the measurement is taken from the take-off line to the nearest point of contact on the landing (back of the heels). Record the longest distance jumped, the best of three attempts.

\section{Illinois Agility Test}

Agility is an important component of many team sports, though it is not always tested, and is often difficult to interpret results. The Illinois Agility Test (Getchell, 1979) is a commonly used test of agility in sports, and as such there are many norms available and as the name it indicates the purpose of this test is to measure agility.

\section{Procedure and Analysis}

The length of the course is 10 meters and the width (distance between the start and finish points) is 5 meters. Four cones are used to mark the start, finish and the two turning points. Another four cones are placed down the center an equal distance apart. Each cone in the center is spaced 3.3 meters apart. Subjects should lie on their front (head to the start line) and hands by their shoulders. On the 'Go' command the stopwatch is started, and the athlete gets up as quickly as possible and runs around the course in the direction indicated, without knocking the cones over, to the finish line, at which the timing is stopped (www.topendsport.com). 
T-Test

The main purpose of this test is, testing agility of athletes, and includes forward, lateral, and backward running.

Procedure and Analysis

Set out four cones as illustrated in the diagram above $(5$ yards $=4.57 \mathrm{~m}, 10$ yards $=9.14 \mathrm{~m})$. The subject starts at cone A. On the command of the timer, the subject sprints to cone B and touches the base of the cone with their right hand. They then turn left and shuffle sideways to cone $\mathrm{C}$, and also touch its base, this time with their left hand. Then shuffling sideways to the right to cone $\mathrm{D}$ and touching the base with the right hand, then shuffle back to cone B touching with the left hand and run backwards to cone A. The stopwatch is stopped as they pass cone A.

\section{Speed Tests}

The purpose of this test was to determine acceleration, maximum running speed of subjects.

\section{Procedure and Analysis}

The test involves running a single maximum sprint over a set distance, with time recorded. After a standardized warm up, the test is conducted over a certain distance, such as 10, 20, 40 and/or 50 meters or yards, depending on the sport and what you are trying to measure. The starting position should be standardized, starting from a stationary position with a foot behind the starting line, with no rocking movements. If you have the equipment (e.g. timing gates), you can measure the time to run each split distances (e.g. 5, 10, 20m) during the same run, and then acceleration and peak velocity can also be determined. It is usual to give the athletes an adequate warmup and practice first, and some encouragement to continue running hard past the finish line.

\section{Methods of Data Analysis}

The data collected through a serious of skill related physical fitness tests was presented as a group mean value and standard deviations. And the effects of anaerobic training on variables were analyzed in separate two pre coded groups experimental (EG) and control group (CG) twice, pre and posttests. And the difference between each test result was analyzed statically with " $\mathrm{t}$ " test at $\mathrm{p}<0.05$ through the use of computerized statically package software (SPSS) version 20

\section{RESULTS AND DISCUSSION}

This chapter discussed the analysis of data collected from the samples of study and its results. The purpose of this study was to investigate the effect of three months of anaerobic training on agility, power and speed of Injibara town U-17 Handball trainees. A pretest of Agility (Illinois agility and t-test), power (Vertical and standing long jump) and speed test of 10 and 40 meter dash test were given. The trainees continued their Handball training which was given three times per a week; simultaneously half of them were randomly selected and subjected to three months of anaerobic training.

Consequently during test on the same parameters and tests were given after six weeks of training and Then at the end of three months of anaerobic training (post) similar tests were given for all 26 Handball trainees regardless of their groups so as to evaluate whether anaerobic training affects agility, power and speed of U-17 Handball trainees or not. Then finding obtained after three months core training program are presented below in tables and analyzed graphically. Table 1 and 2 shows physical features and Table 3 and 4, show the statistics for agility, power and speed test scores. The abbreviations used in the research were as follows: Experimental Group (EG), Control Group (CG), Illinois Agility Test (IAT), T-test (TT), Vertical Jump Test (VJT), Standing Long Jump Test (SLJT), 10 meter dash (ST1) and 40 meter dash for speed test (ST2).

Body weight averages of the groups in the research are as follows; U-17 EG=56.92 Kg; $\mathrm{CG}=57.77$ and height averages of the groups in the study are as follows; $\mathrm{U}-17 \mathrm{EG}=1.68 \mathrm{~m} ; \mathrm{CG}=1.71 \mathrm{~m}$.

Table 1 Body weight and height averages of the groups $(\mathrm{Kg})$

\begin{tabular}{llll}
\hline Groups & N & Weight(Kg) & Height (m) \\
\hline U-17 EG & 13 & 56.92 & 1.68 \\
U-17 CG & 13 & 57.77 & 1.71 \\
Total & 26 & & \\
\hline $\begin{array}{l}X=\text { value mean, } S D=\text { standard deviation, } N=\text { number of players in a group, EG= Experimental groups, CG= } \\
\text { control groups. }\end{array}$
\end{tabular}


Table 2 PT, DT \& POT results of IAT and T-test of the Groups.

\begin{tabular}{lllllll}
\hline Groups & $\mathbf{N}$ & $\mathbf{P T}(\mathbf{X}, \pm \mathbf{S D})$ & $\mathbf{D T}(\mathbf{X}, \pm \mathbf{S D})$ & $\mathbf{P o T}(\mathbf{X}, \pm \mathbf{S D})$ & $\Delta \mathbf{X}(\mathbf{P o T}$ & $\mathbf{P} \& \mathbf{P T}$ \\
\hline IAT result of EG & 13 & $17.836 \pm 0.5737$ & $17.6869 \pm .5737$ & $17.455 \pm 0.5486$ & -.381 & .001 \\
IAT result of CG & 13 & $17.8277 \pm .7579$ & $17.7123 \pm .7015$ & $17.4592 \pm .5701$ & -.3685 & .017 \\
TT result of EG & 13 & $11.372 \pm 0.4765$ & $11.2077 \pm .4748$ & $10.634 \pm 0.2960$ & -.738 & .000 \\
TT result of CG & 13 & $11.5023 \pm .4797$ & $11.3846 \pm .4116$ & $11.1254 \pm .4650$ & -.3769 & .005 \\
\hline
\end{tabular}

$E G=$ experimental groups, IAT=Illinois agility test, $T T=t$-test of agility, $X=$ mean value of each tests, $\Delta X=(M D)$ mean difference, $P T=$ pretest result, $D T=$ during training PoT= post test results, $t$ - $t$ value, $d f=d e g r e e ~ o f ~ f r e e d o m$, p=significance level.

As Table2: shows that Pre, DT and post IAT test mean of EG was 17.836, 17.6869 and post IAT test mean was 17.455resrespectively. And of the CGPT, DT and PoT result of IAT mean was 17.8277, 17.7123 and 17.4592 respectively. And also PT, DT and PoT test results of the EG was11.372, 11.2077 and 10.634 respectively. And also the CG was $11.5023,11.3846$ and 11.1254 respectively. So these data indicated that there is a significant difference and gradual improvement between PT, DT and PoT test results of both the EG and CG.

In which incase of the EG, duration of Illinois agility run test was significantly less by a mean difference of 0.381 at $\mathrm{P}=0.001$ and duration of T-test was significantly decreased by a PT and PoT mean difference of .738. At $\mathrm{P}=0.000$ after three months of anaerobic training. And also in case of the $\mathrm{CG}$, in which duration of Illinois agility run test was significantly less by a mean difference of .3685 at $\mathrm{P}=.017$ and duration of $\mathrm{T}$-test was significantly decreased by a mean difference of .3769 at $\mathrm{P}=0.005$. As a result the investigator accepted alternative hypothesis 1 and rejected the null hypothesis. And is confirmed with this finding, Pankajbhai and Shantilal(2015) found in their research conducted on effect of core stability training on speed of running in female cricket players that, two weeks of core stability training improves speed of running and agility in selected female cricket players as measured by $4 \times 10 \mathrm{~m}$ shuttle run test and T test for agility.

Figure 1: Graphical presentation of IAT and T Test result of both groups

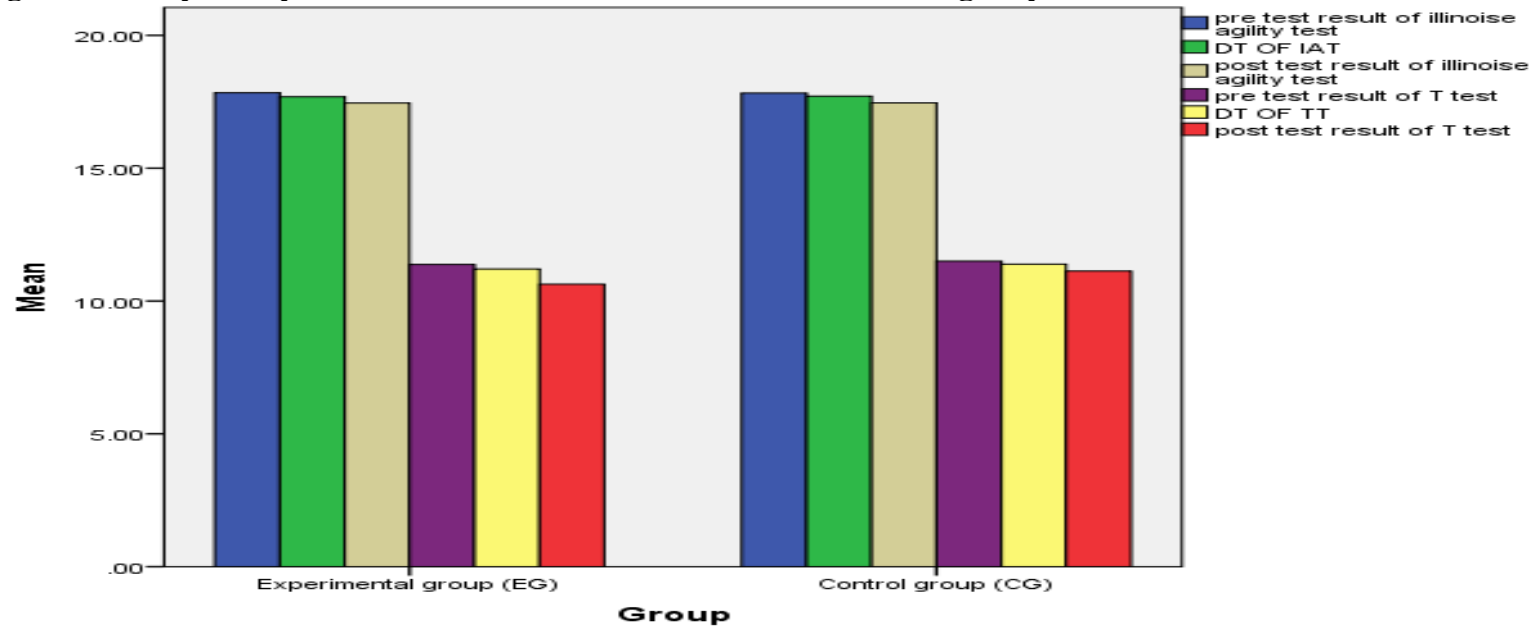

As the collected data and graph indicated; even if both EG and CG had a significant change at $p<0.05$, there is a difference in their pre and post mean values of both agility tests, in which mean difference in t- test of EG was 0.738 . At $\mathrm{P}=0.000$ which is relatively high change than mean difference in t- test of $\mathrm{CG} 0.3769$ at $\mathrm{P}=0.005$. But in case of Illinois agility test there is no much difference among pre and posttest mean of both EG and CG beyond to their significant change listed above.

Table 3 PT, DT\& POT results of VJT and SLJT of the Groups.

\begin{tabular}{lllllll}
\hline Groups & $\mathbf{N}$ & $\mathbf{P T}(\mathbf{X}, \pm$ SD) & $\mathbf{D T}(\mathbf{X}, \pm$ SD $)$ & PoT $(\mathbf{X}, \pm$ SD $)$ & $\Delta \mathbf{X}(\mathbf{M D})$ & P \\
\hline VJT result of EG & 13 & $0.82 \pm 0.03$ & $.8369 \pm .02983$ & $0.88 \pm 0.035$ & .06 & .000 \\
VJT result of CG & 13 & $.8154 \pm .04977$ & $.8215 \pm .04432$ & $.8408 \pm .05693$ & .0254 & .038 \\
SLJT result of EG & 13 & $2.1354 \pm .1367$ & $2.1562 \pm .1238$ & $2.2515 \pm 0.8315$ & .1161 & .003 \\
SLJT result of CG & 13 & $2.0877 \pm .13498$ & $2.0923 \pm .1357$ & $2.1185 \pm .14736$ & .0308 & .052 \\
\hline
\end{tabular}

$E G=$ experimental groups, $N=$ number of players in a group, $V J T=$ vertical jump test, $S L J T=$ standing long jump test, $P T=$ test before training, $D T=$ during training PoT=test after three months of training, $t=v a l u e, d f=d e g r e e$ of freedom, $p=$ level of significance, $\Delta X=(M D)$ mean difference.

As Table 2: shows that EG Pre, during and post VJT test mean was $0.82,0.8369$ and 0.88 respectively. The CG,PT, DT and PoT result of VJT mean was $0.8154, .8215$ and.8408 respectively. So these data indicated that there is a significant difference and gradual improvement between PT, DT and post test results of both groups. In which incase of the EG, height of VJT test result was significantly increased by a PT and PoT mean difference of 
0.06 at $\mathrm{P}=.000$, after three months of anaerobic training. In case of the $\mathrm{CG}$, height of $\mathrm{VJT}$ result was significantly increased by a mean difference of 0.0254 At $\mathrm{P}=0.038$ but in case of the second power test which is SLJT, a significant difference and gradual improvements was obtained only at the EG in which there PT, DT and post test result was 2.1354, 2.1562 and 2.2515 respectively. In which length of SLJT result of this groups is increased by a PT and PoT mean difference of 0.1161 at $\mathrm{P}=0.003$. But based on the pre given significance value in which the mean difference of pre and post SLJT result of the CG was 0.0308 at P $>0.05$. Since the only improvement was shown by the EG, the researcher accepted alternative hypothesis 2 and rejected the null one. And it is confirmed with the following findings.

Tarik. O, (2016) found in their research conducted on Relationship between core stability, dynamic balance and jumping performance in Handball players that core stability is associated with jump height in Handball players.

Heydar .S et al(2013) showed in their research conducted on The effect of six- week core stability exercises on performance of male athlete, 11-14 years old that significant increment was observed in Performance tests of (Standing Broad Jump, Vertical Jump, 9.1 m Sprint, Shuttle Run) and recommend the core stability exercises to improve general performance of athletes. Thus it is in conformity with the finding of this study.

Figure 2: Graphical presentation of VJT and SLJT (power) test of both groups.

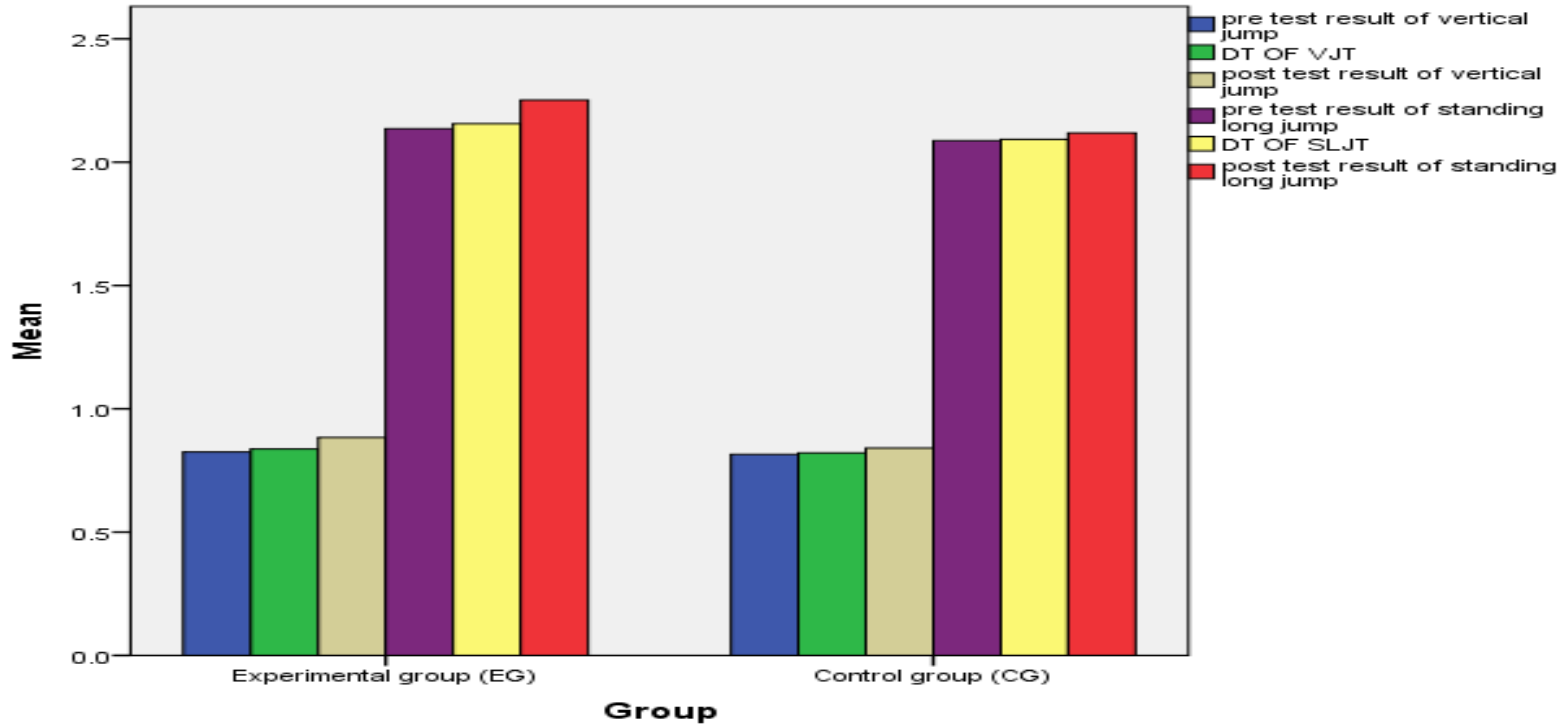

As the above data and graph indicated; even if both EG and CG had a significant change in VJT at $\mathrm{p}<0.05$, there is a difference in their pre and post mean values of SLJT in which mean difference in EG was .06 at $\mathrm{P}=0.000$ which is relatively high change than mean difference in vertical jump test of $\mathrm{CG} .0254$ at $\mathrm{P}=.038$. And in case of SLJT; there is also difference between a pre and posttest mean difference values of both EG and CG which is .1161 at $\mathrm{P}=0.003$ and .0308 at $\mathrm{P}=.052$ respectively.

Table. 4. PT, DT \& PoT results of $10 \mathrm{~m}$ and $40 \mathrm{~m}$ dash tests of both groups

\begin{tabular}{lllllll}
\hline Groups & $\mathbf{N}$ & $\mathbf{P T}(\mathbf{X}, \pm$ SD) & $\mathbf{D T}(\mathbf{X , S D})$ & PoT $(\mathbf{X}, \pm$ SD) & $\Delta \mathbf{X}(\mathbf{M D})$ & P \\
\hline ST1 of EG & 13 & $1.8700 \pm .1403$ & $1.8415 \pm .1197$ & $1.7308 \pm 0.1219$ & -.1392 & .006 \\
ST1 of CG & 13 & $1.9900 \pm .17574$ & $1.9654 \pm .1579$ & $1.8638 \pm .18728$ & -.1262 & .020 \\
ST2 of EG & 13 & $7.6000 \pm .2707$ & $7.5085 \pm .2616$ & $7.3985 \pm .2982$ & -.2015 & .008 \\
ST2 of CG & 13 & $7.5708 \pm .36716$ & $7.5292 \pm .4011$ & $7.4415 \pm .4011$ & -.1293 & .010
\end{tabular}

$E G=$ experimental groups, $N=$ number of players in a group, $S T 1=$ speed test $1(10$ meter dash $)$, ST2 = speed test 2(40 meter dash), PT=test before training, DT= test during training, PoT=test after three months of training, $t=$ value, $d f=$ degree of freedom, $p=$ level of significance, $\Delta X=(M D)$ mean difference.

As Table 4: shows that Pre, during and posttest result of ST1 (10mdash) test mean of EG was 1.8700, 1.8415and1.7308 respectively. And of the CG, Pre DT and PoT test mean was 1.9900, 1.9654 and1.8638 respectively. And also pre, during and post ST2 test results of the EG was7.6000, 7.5085 and 7.3985 respectively. And also the CG was 7.5708, 7.5292 and 7.4415 respectively. Therefore these data indicated that there is a significant difference and gradual improvement of players speed between three consecutive tests of both the EG and CG. In which incase of the EG, duration of 10m dash speed test (ST1) was significantly less by a PT and PoT mean difference of .1392 at $\mathrm{P}=.006$ and duration of $40 \mathrm{~m}$ dash speed test (ST2) was significantly decreased by a mean difference of .2015 . At $P=.008$ after three months of anaerobic training. And also in case of the $C G$, in 
which duration of $10 \mathrm{~m}$ dash speed test (ST1) was significantly less by a mean difference of .1262 at $\mathrm{P}=.020$ and duration of $40 \mathrm{~m}$ dash speed test (ST2) was significantly decreased by a mean difference of.1293 at $\mathrm{P}=.010$. As a result the investigator accepted alternative hypothesis 3 and rejected the null hypothesis. And the following researchers supported this study.

Thomas and William (2009) found in their research conducted on a female volleyball team that $40 \mathrm{~m}$ sprint speed improved after core training: thus, it is in conformity with the finding of this study.

Natalia Niewolna and Teresa ZwierkoA (2015) found in their research conducted on The Effect of three months anaerobic exercises on Selected Speed and Strength Parameters in Expert Female Handball players, There was also a significant reduction in the time of 30 meter sprint at $p<0.05$, Thus it is also in conformity with the finding of this study.

Figure: 3 Graphical presentation ofST1 $(10 \mathrm{~m})$ and ST2 (40m dash) speed test the group

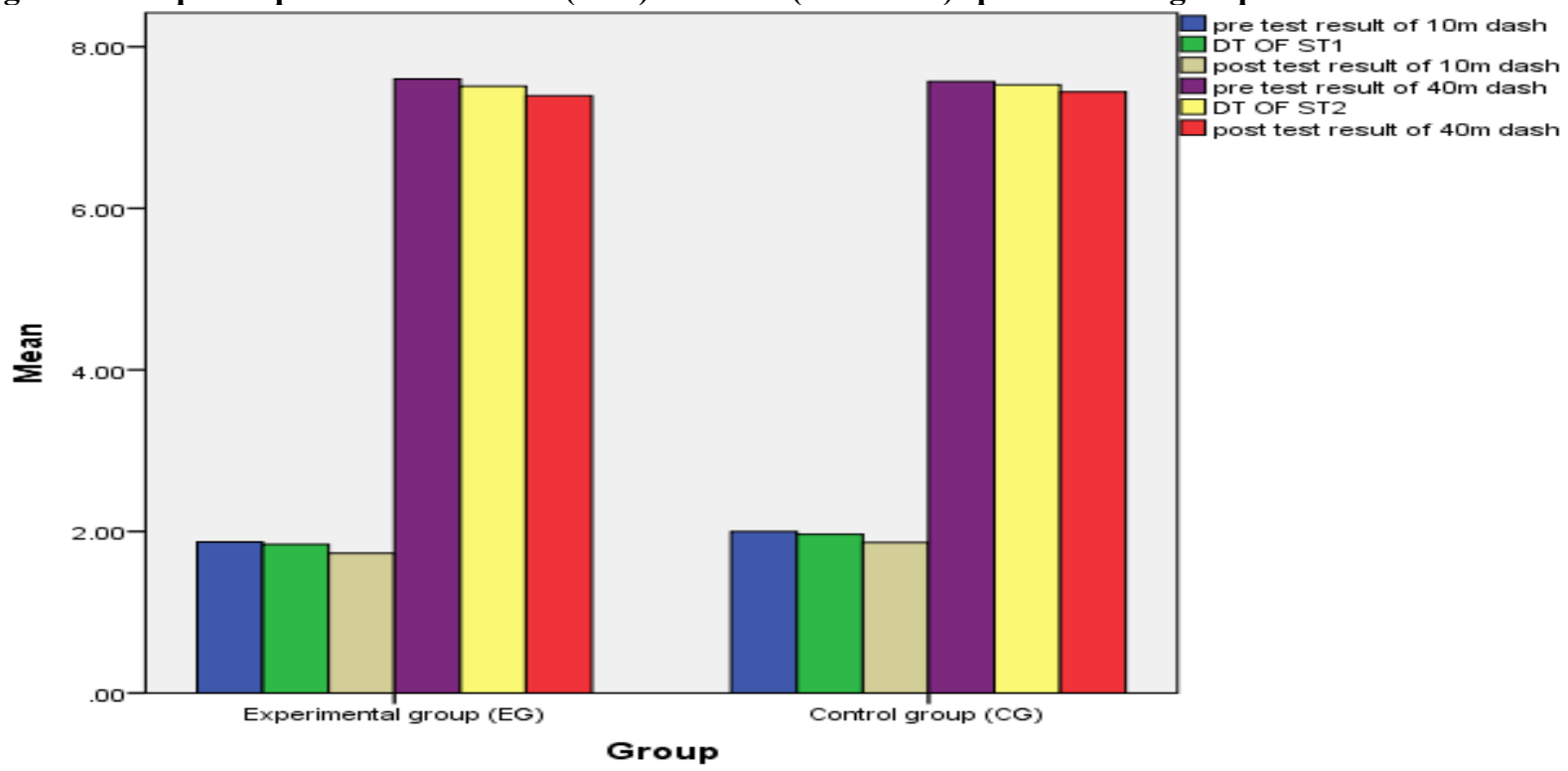

As the collected data and graph indicated; even if both EG and CG had a significant change and gradual improvements in each tests. There is only a little difference in change of pre and post mean values of both $10 \mathrm{~m}$ and $40 \mathrm{~m}$ dash speed test, in which mean difference in $10 \mathrm{~m}$ dash speed test of EG and CG was 0.1392 . At $\mathrm{P}=$ 0.006 and .1262 at $\mathrm{P}=0.020$ respectively. And also pre and post mean differences in ST2 (40 meter dash speed test) of EG and CG was 0.2015 at $\mathrm{P}=0.008$ and 0.1293 at $\mathrm{P}=0.010$ which was a little or no change between both groups were observed here. Generally, three months of anaerobic training has a significant change of improvement in speed, power and agility of U-17 Experimental groups than control groups though three months of regular Handball training has its own positive effect on such skills too.

\section{Conclusions}

Based on the major findings of the study the following points were stated as a conclusion.

* The result of the study showed that 3 months of anaerobic training has relative positive effect on agility of U-17 Handball trainees as measured by Illinois agility and T-test.

* The output of the study showed that 3 months of anaerobic training has a significant improvement on power of U-17 Handball trainees.

* The finding of this study yields a significant benefit on improvement of Handball trainee's speed.

* In general after three months of anaerobic training, statistically significant improvement and change were observed in U-17 Handball player's agility, power and speed. This result is supported by the study findings conducted by Afiyon. A, stated in his research done on 16 years old Handball players that 12 weeks anaerobic training has an explosive effect on player's motoric capabilities such as; standing long jump, shuttle run, speed, plank, and vertical jump which are some of an important parameters of Handball speed power and agility. Therefore this finding complies with this study.

\section{REFERENCES}

A. Faigenbaum (2001), appropriately designed and competently supervised, youth strength training programs can offer observable health and fitness value to boys and girls

Baechle, T. R. (1994), essentials of Strength and Conditioning. Champaign IL Human Kinetics 
Baker, D. (1999b) the Relation between Running Speed and Measures of Strength and Power in Professional Rugby League Players Journal of Strength and Conditioning Research, 13,230

Baker, D. (1999b) the Relation between Running Speed and Measures of Strength and Power in Professional Rugby League Players Journal of Strength and Conditioning Research, 13,230

Barrow \& McGee, R. (1971), a Practical Approach to Measurment in Physical Education. Philadelphia. Pa: Lea \& Fibiger

Baumgartner, T. \& Jackson, A (1975).Measurement For Evaluation in Physical Education. Boston. Ma: Houghton Mifflin

Baumgartner, T. \& Jackson, A (1975).Measurement For Evaluation in Physical Education. Boston. Ma: Houghton Mifflin

Bernier, M. (2003): Perturbation and Agility Training In the Rehabilitation of Handball Athletes Athletic Therapy Today. 8(3), 2022

Brandon, R. (1999) stated that practicing the correct sprint bounding technique would improve your sprinting efficiency when properly practiced.

Brandon, R. (1999) stated that practicing the correct sprint bounding technique would improve your sprinting efficiency when properly practiced.

David Joyce, (1960),speed bounding are the key components of a workout designed dramatically enhance your speed and power performance for Handball players.

David Joyce, (1960),speed bounding are the key components of a workout designed dramatically enhance your speed and power performance for Handball players.

Davis and Brewer, (1992), the programs are Comparable to those of elite British female Handball players, who train on five occasions each week during the season.

Davis, B. Et Al. (2000) Physical Education and the Study of SportUk: Harcourt Publishers Ltd.

Galligan, F. Et Al. (2000) Advanced Pe For Edexcel. Oxford; Heinemann Educational Publishers

Hall, (1999) sprinter's task as mentioned is to drive or thrust downward and backward against the ground.

Jens Bangsbo, (1994), anaerobic training in Handball is to increase a player's potential to perform highintensity exercise during a game.

Jens Bangsbo, (1994), anaerobic training in Handball is to increase a player's potential to perform highintensity exercise during a game.

Pearson, A. (2001) Speed, Agility and Quickness for Handball. London: A. and C. Black

Pearson, A. (2001) Speed, Agility and Quickness for Handball. London: A. and C. Black

Peltola with Thomson \& Beavis, (1992),parameters have designed to predict performance capacity, taking in to account the player's current level of fitness.

Reilly and Drust, (1994), top women Handball players tend to have greater muscle strength values than university players or non-games players.

Reilly et al. (2000) found that performance in an agility run test was the best distinguishing feature of the elite individuals "on comparing elite 15-16-year old players with age-matched sub-elite Handball players".

Singh (2007), players of trained were found significantly better on all physical fitness variables i.e. strength, speed, power, flexibility, agility and endurance that of non- trained one.

Wesley Hit and Getty April 23, (2015) Squat jumps and ply metric jumps are basic drills that improve agility and power and help increase an athlete's vertical jump.

\section{APPENDIX-A \\ Information record form}

The questionnaire prepared for researching entitled "the effect of anaerobic training on Handball skills related fitness components on Injibara town u-17 Handball Trainees at Awi zone Amhara regional state." so you are kindly requested to give appropriate information for the following question regarding to your current health status.

Thank you.

I. Player's information

Name_t Telephone number

Sex Age

Grade Section

Positional interest of play

Emergency contact information

Full name address tel.

II. Personal health history(answer yes or no and give description if necessary)

1. Have you taken a physical fitness test beyond your regular Handball training before?

2. Have you taken any Handball related skill tests before? 
3. Do you know your current level of physical fitness?

4. Are you currently undergoing any medical treatment or under observation?

5. Have you fallen sick in the past 3 months? if yes, please write your problem

6. Have you injured seriously while you play Handball in the past three months/summer? parts of injury you got and in which body parts?

7. Had you a major surgery in the last 3 months

I have read and understand the form and have given accurate information regarding to my current health status.

Signed (participant player) date

Signed (examiner) date

\section{APPENDIX-B}

\section{Sample Consent Form}

I (print name)

hereby consent to participating in the anthropometric test and three months of scientific studies which is conducted on the effect of anaerobic training on U- 17 Handball trainees on the following terms:

I have been informed about the wellness, current status of health assessment and questionnaires, the training procedures and understand what I will berequired to do. And I understand that I will be partaking in three months of anaerobic training besides the regular Handball training.

I understand that there is always a risk of injury associated with strength and Handball training. And I can withdraw my consent, freely and without prejudice, at any time.

I understand that the information obtained from the test will be treated confidentially, with my right to privacy assured. However, the information obtained may be used for statistical analysis or scientific purpose with my right to privacy retained.

And I accept that: this is my personal interest and willingness to participate in any of the necessary procedures which involves in any steps of this study as possible.

Participant signature Date

Parent/Guardian name (if under the age of 18)

Parent/Guardian signature

Date

\section{APPENDIX - C}

Table of Paired sample $T$ test results of both groups

Table 1. Descriptive statistics of the $\mathbf{C G}$

\begin{tabular}{|ll|l|l|l|}
\hline Pre and Posttest statistics of CG & Mean & $N$ & Std. D \\
\hline \multirow{2}{*}{ Pair 1 } & pretest result of IAT & 17.8277 & 13 & .75794 \\
& during test result of IAT & 17.7123 & 13 & .70156 \\
& post test result of IAT & 17.4592 & 13 & .57018 \\
Pair 2 & pretest result of TT & 11.5023 & 13 & .47974 \\
& during test result of TT & 11.3846 & 13 & .41186 \\
& post test result of TT & 11.1254 & 13 & .46506 \\
Pair 3 & pretest result of VJT & .8154 & 13 & .04977 \\
& during test result of VJT & .8215 & 13 & .04432 \\
& post test result of VJT & .8408 & 13 & .05693 \\
Pair 4 & during test result of SLJT & 2.0877 & 13 & .13498 \\
& post test result of SLJT & 2.0923 & 13 & .13572 \\
& pretest result of ST1 & 2.1185 & 13 & .14736 \\
Pair 5 & during post test result of SPT1 & 1.9900 & 13 & .17574 \\
& post test result of ST1 & 1.9654 & 13 & .15794 \\
& pretest result of ST2 & 1.8638 & 13 & .18728 \\
Pair 6 & during test result of ST2 & 7.5708 & 13 & .36716 \\
& post test result of ST2 & 7.592 & 13 & .36246 \\
\hline
\end{tabular}


Table 2.Paired Sample T test of CG

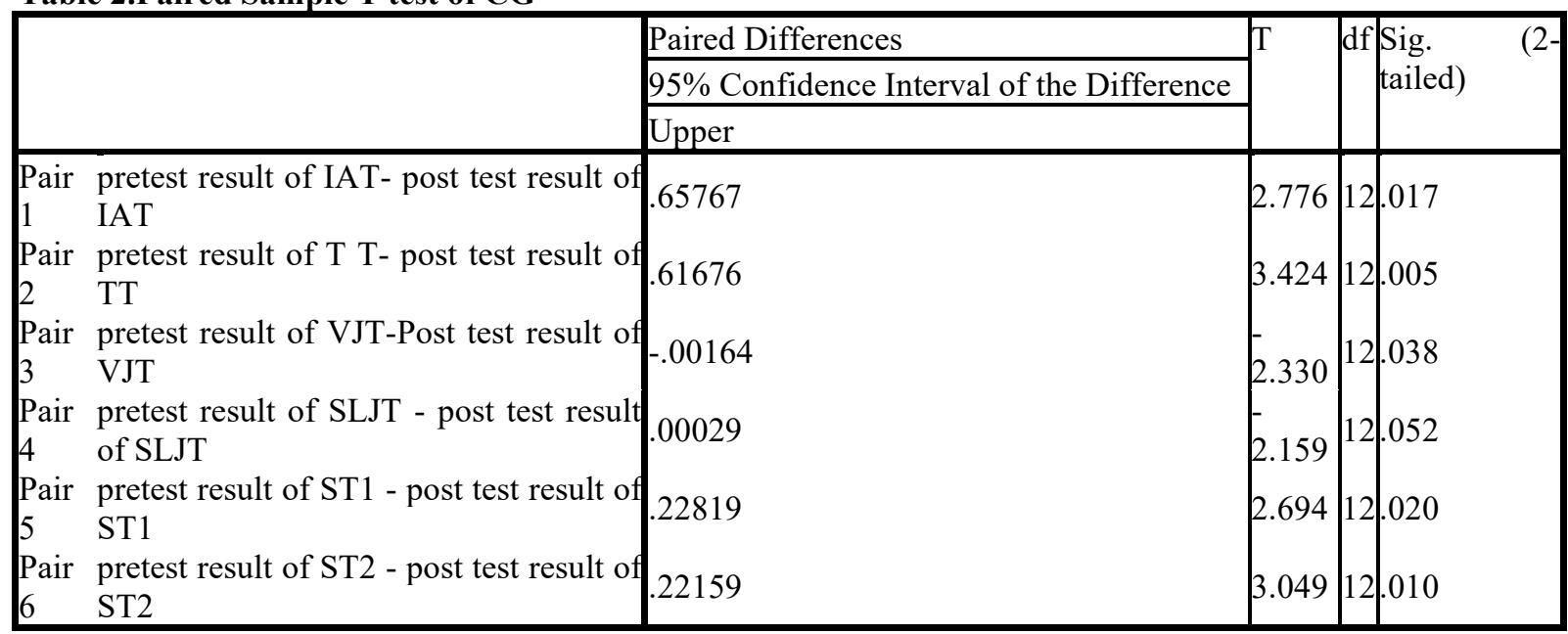

Table.3.Descriptive Statistics of the EG

\begin{tabular}{|c|c|c|c|c|}
\hline & & Mean & $\mathrm{N}$ & Std. D \\
\hline \multirow{3}{*}{ Pair 1} & pretest result of IAT & 17.8362 & 13 & .57372 \\
\hline & during test result of IAT & 17.6869 & 13 & .5053 \\
\hline & post test result of IAT & 17.4546 & 13 & .54863 \\
\hline & pretest result of TT & 11.3723 & 13 & .47654 \\
\hline \multirow[t]{3}{*}{ Pair 2} & during test result of TT & 11.2077 & 13 & .4748 \\
\hline & post test result of TT & 10.6338 & 13 & .29596 \\
\hline & pretest result of VJT & .82 & 13 & .030 \\
\hline \multirow{2}{*}{ Pair 3} & during test result of $\mathrm{VJT}$ & .8369 & 13 & .0298 \\
\hline & post test result of VJT & .88 & 13 & $\begin{array}{r}.035 \\
.1238\end{array}$ \\
\hline \multirow{4}{*}{ Pair 4} & pretest result of SLJT & 2.1354 & 13 & \\
\hline & during test result ofSLJT & 2.1562 & 13 & $.136 / 2$ \\
\hline & post test result of SLJT & 2.2515 & 13 & .08315 \\
\hline & pretest result of ST1 & 1.8700 & 13 & .14030 \\
\hline \multirow[t]{3}{*}{ Pair 5} & during test result ofST1 & 1.8415 & 13 & .1197 \\
\hline & post test result of SPT1 & 1.7308 & 13 & .12189 \\
\hline & pretest result of SPT2 & 7.6000 & 13 & .27074 \\
\hline \multirow[t]{2}{*}{ Pair 6} & during test result of ST2 & 7.585 & 13 & .2616 \\
\hline & post test result of SPT3 & 7.3985 & 13 & .29816 \\
\hline
\end{tabular}

Table.4. Paired Sample T test of EG

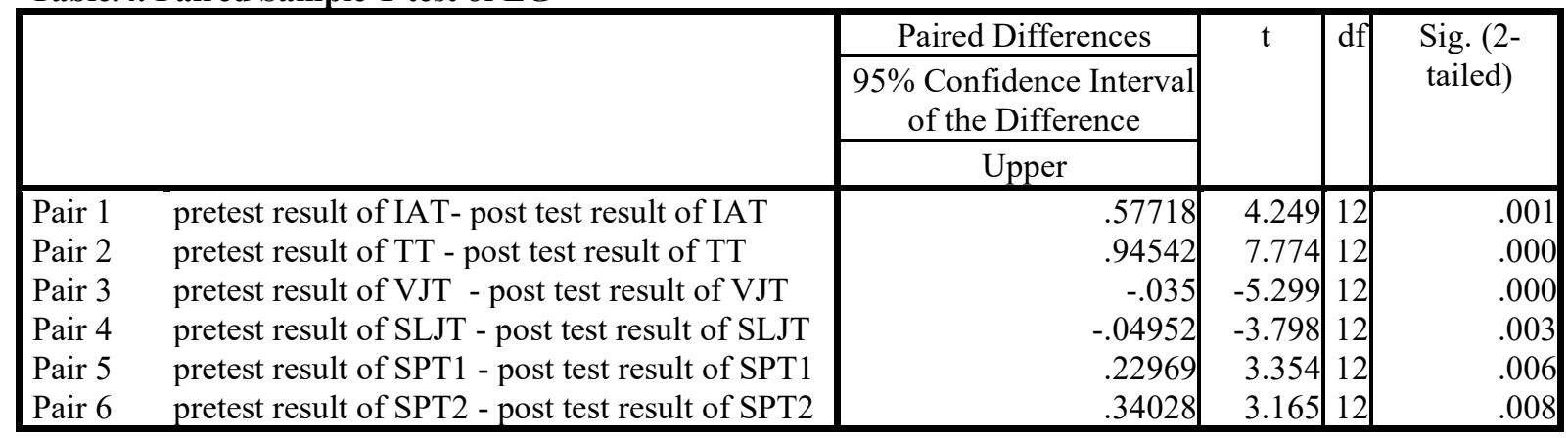




\section{APPENDIX-D}

Three Months of anaerobic Training plan

Table 10: First Month Training Schedule (January, 2019)

\begin{tabular}{|c|c|c|c|c|c|c|c|}
\hline \multirow{2}{*}{$\begin{array}{lll}\text { Days per a } \\
\text { week }\end{array}$} & \multirow[t]{2}{*}{ Types of Exercises } & \multicolumn{5}{|c|}{ Time } & \multirow[t]{2}{*}{ Intensity } \\
\hline & & $\begin{array}{l}\text { No. } \\
\text { rep }\end{array}$ & $\begin{array}{l}\text { No. } \\
\text { set }\end{array}$ & $\begin{array}{l}\text { time } \\
\text { in } \\
\text { each } \\
\text { sets } \\
\end{array}$ & $\begin{array}{l}\text { Recovery } \\
\text { time }\end{array}$ & $\begin{array}{l}\text { Total } \\
\text { time } \\
(35- \\
\text { 40min }) \\
\end{array}$ & \\
\hline $\begin{array}{l}\text { Monday 5:00- } \\
\text { 5:40 PM }\end{array}$ & $\begin{array}{l}1 \text {.General and specific warming up } \\
\text { exercises walking, jogging, running } \\
\text { on spot with relaxation, rotating } \\
\text { activities and stationed general and } \\
\text { specific stretching activities. } \\
\text { 1.side bend } \\
\text { 2. reverse plank with leg raise } \\
\text { 3.squat } \\
\text { 4.situps } \\
\text { 5.six inch } \\
\text { 6. Russian twist } \\
\text { 7.leg and hip raiser } \\
\text { 8. Cool down breathing, stretching } \\
\text { exercises. }\end{array}$ & $\begin{array}{l}- \\
10 \\
15 \\
10 \\
\overline{15} \\
15\end{array}$ & $\begin{array}{l}2 \\
2 \\
2 \\
2 \\
3 \\
3 \\
3\end{array}$ & $\begin{array}{l}30 \mathrm{sec} \\
- \\
- \\
\overline{1} 5 \mathrm{sec} \\
- \\
-\end{array}$ & $\begin{array}{l}30 \mathrm{sec} \\
30 \mathrm{sec} \\
30 \mathrm{sec} \\
30 \mathrm{sec} \\
30 \mathrm{sec} \\
20 \mathrm{sec} \\
30 \mathrm{sec}\end{array}$ & $\begin{array}{l}2 \mathrm{~min} \\
2 \mathrm{~min} \\
3 \mathrm{~min} \\
3 \mathrm{~min} \\
3 \mathrm{~min} \\
2 \mathrm{~min} \\
3 \mathrm{~min} \\
5 \mathrm{~min}\end{array}$ & $\begin{array}{c}60-70 \% \\
\text { of } \\
\text { maximum } \\
\text { strength }\end{array}$ \\
\hline $\begin{array}{l}\text { Wednsday5:00- } \\
\text { 5:40 PM }\end{array}$ & $\begin{array}{l}\text { 1. Warming up by } 3 \text { Vs } 3 \text { ball game } \\
\text { and specific warming up running on } \\
\text { spot with relaxation, rotating } \\
\text { activities and stationed general and } \\
\text { specific stretching activities. } \\
\text { 1. Crunches } \\
\text { 2. Reverse crunches } \\
\text { 3. Hip raiser } \\
\text { 4.the } L \text { sit } \\
\text { 5.pushup to side plank } \\
\text { 6.flutter kick } \\
\text { 7.russian twist } \\
\text { 8.single climbers } \\
\text { 9.cooling down and stretching } \\
\text { exercises }\end{array}$ & $\begin{array}{l}15 \\
15 \\
15 \\
- \\
15 \\
- \\
20 \\
25\end{array}$ & $\begin{array}{l}\mathbf{3} \\
\mathbf{3} \\
\mathbf{2} \\
\\
\mathbf{3} \\
\mathbf{3} \\
\mathbf{2} \\
\mathbf{3} \\
\mathbf{3}\end{array}$ & $\begin{array}{l}- \\
- \\
- \\
15 \mathrm{sec} \\
\overline{20} \mathrm{sec} \\
- \\
-\end{array}$ & $\begin{array}{l}15 \mathrm{sec} \\
20 \mathrm{sec} \\
20 \mathrm{sec} \\
15 \mathrm{sec} \\
10 \mathrm{sec} \\
10 \mathrm{sec} \\
20 \mathrm{sec} \\
20 \mathrm{sec}\end{array}$ & $\begin{array}{l}3 \mathrm{~min} \\
3 \mathrm{~min} \\
2.5 \mathrm{~min} \\
1.5 \mathrm{~min} \\
2 \mathrm{~min} \\
1.5 \mathrm{~min} \\
2.5 \mathrm{~min} \\
2 \mathrm{~min} \\
6 \mathrm{~min}\end{array}$ & $\begin{array}{c}60-70 \% \\
\text { of } \\
\text { maximum } \\
\text { strength }\end{array}$ \\
\hline $\begin{array}{l}\text { Friday at 7:00- } \\
\text { 7:40 AM }\end{array}$ & $\begin{array}{l}1 \text {.General and specific warming up } \\
\text { exercises walking, jogging, running } \\
\text { on spot with relaxation, rotating } \\
\text { activities and stationed general and } \\
\text { specific stretching activities. } \\
\text { 2. Oblique } \\
\text { 3. Alternative crunch } \\
\text { 4.Bicycle } \\
\text { 5. Superman } \\
\text { 6.bird dog } \\
\text { 7.single plank } \\
\text { 8.single leg stabilizers } \\
\text { 9.outsiders } \\
\text { 10. Cooling down and stretching } \\
\text { activities }\end{array}$ & $\begin{array}{l}20 \\
20 \\
15 \\
15 \\
20 \\
- \\
\overline{20}\end{array}$ & $\begin{array}{l}3 \\
\mathbf{2} \\
\mathbf{2} \\
\mathbf{3} \\
\mathbf{3} \\
\mathbf{2} \\
\mathbf{2} \\
\mathbf{3}\end{array}$ & $\begin{array}{l}- \\
- \\
- \\
- \\
\overline{2} 0 \mathrm{sec} \\
25 \mathrm{sec} \\
-\end{array}$ & $\begin{array}{l}10 \mathrm{sec} \\
15 \mathrm{sec} \\
15 \mathrm{sec} \\
10 \mathrm{sec} \\
15 \mathrm{sec} \\
10 \mathrm{sec} \\
10 \mathrm{sec} \\
20 \mathrm{sec}\end{array}$ & $\begin{array}{l}3 \mathrm{~min} \\
3 \mathrm{~min} \\
2.5 \mathrm{~min} \\
1.5 \mathrm{~min} \\
2 \mathrm{~min} \\
1.5 \mathrm{~min} \\
2.5 \mathrm{~min} \\
3 \mathrm{~min} \\
6 \mathrm{~min}\end{array}$ & $\begin{array}{c}\text { 70-90\% } \\
\text { of } \\
\text { maximum } \\
\text { strength }\end{array}$ \\
\hline
\end{tabular}


Table: 11. Second Month Training Schedule (February, 2019)

\begin{tabular}{|c|c|c|c|c|c|c|c|}
\hline \multirow{2}{*}{$\begin{array}{l}\text { Days } \\
\text { per a } \\
\text { week }\end{array}$} & \multirow[t]{2}{*}{ Types of Exercises } & \multicolumn{5}{|c|}{ Time } & \multirow[t]{2}{*}{ Intensity } \\
\hline & & $\begin{array}{l}\text { No. } \\
\text { rep }\end{array}$ & $\begin{array}{l}\text { No. } \\
\text { set }\end{array}$ & $\begin{array}{l}\text { time in } \\
\text { each sets }\end{array}$ & $\begin{array}{l}\text { Recove } \\
\text { r time }\end{array}$ & $\begin{array}{l}\text { Total } \\
\text { time(35- } \\
\text { 40min) }\end{array}$ & \\
\hline $\begin{array}{l}\text { Mond } \\
\text { ay } \\
\text { 5:00- } \\
\text { 5:40 } \\
\text { PM } \\
\\
\\
\\
\\
\\
\\
\text { Wedns } \\
\text { day5:0 } \\
0-5: 40\end{array}$ & $\begin{array}{l}1 \text {.General and specific warming } \\
\text { up exercises walking, jogging, } \\
\text { running on spot with relaxation, } \\
\text { rotating activities and stationed } \\
\text { general and specific stretching } \\
\text { activities. } \\
\text { 1.side bend } \\
\text { 2. reverse plank with leg raise } \\
\text { 3.squat } \\
\text { 4.situps } \\
\text { 5.six inch } \\
\text { 6. Russian twist } \\
\text { 7.leg and hip raiser } \\
\text { 8. Cool down breathing, } \\
\text { stretching exercises. }\end{array}$ & $\begin{array}{c}- \\
15 \\
20 \\
25 \\
\overline{20} \\
20\end{array}$ & $\begin{array}{l}2 \\
2 \\
2 \\
2 \\
3 \\
3 \\
3 \\
3\end{array}$ & $\begin{array}{l}30 \mathrm{sec} \\
- \\
- \\
\overline{15} \mathbf{~ s e c} \\
- \\
-\end{array}$ & $\begin{array}{l}30 \mathrm{sec} \\
30 \mathrm{sec} \\
30 \mathrm{sec} \\
30 \mathrm{sec} \\
30 \mathrm{sec} \\
20 \mathrm{sec} \\
\text { 30sec }\end{array}$ & $\begin{array}{l}10 \mathrm{~min} \\
2.5 \mathrm{~min} \\
2.5 \mathrm{~min} \\
2.5 \mathrm{~min} \\
3.5 \mathrm{~min} \\
3 \mathrm{~min} \\
2.5 \mathrm{~min} \\
3 \mathrm{~min} \\
7 \mathrm{~min}\end{array}$ & $\begin{array}{c}60-70 \% \text { of } \\
\text { maximum } \\
\text { strength }\end{array}$ \\
\hline $\begin{array}{l}\text { PM } \\
\\
\\
\\
\text { Friday } \\
\text { at } \\
7: 00- \\
7: 40 \\
\text { AM }\end{array}$ & $\begin{array}{l}\text { 1. Warming up by } 3 \text { Vs } 3 \text { ball } \\
\text { game and specific warming up } \\
\text { running on spot with relaxation, } \\
\text { rotating activities and stationed } \\
\text { general and specific stretching } \\
\text { activities. } \\
\text { 2. Crunches } \\
\text { 3. Reverse crunches } \\
\text { 4. Hip raiser } \\
\text { 5.the L sit } \\
\text { 6.pushup to side plank } \\
\text { 7.flutter kick } \\
\text { 8.russian twist } \\
\text { 9.single climbers } \\
\text { 10.cooling down and stretching } \\
\text { exercises }\end{array}$ & $\begin{array}{l}15 \\
10 \\
10 \\
\overline{10} \\
\overline{15} \\
20\end{array}$ & $\begin{array}{l}\mathbf{3} \\
\mathbf{3} \\
\mathbf{3} \\
\mathbf{3} \\
\mathbf{3} \\
\mathbf{3} \\
\mathbf{3} \\
\mathbf{3}\end{array}$ & $\begin{array}{l}- \\
- \\
- \\
15 \mathrm{sec} \\
\overline{20 s e c} \\
- \\
-\end{array}$ & $\begin{array}{l}15 \mathrm{sec} \\
20 \mathrm{sec} \\
20 \mathrm{sec} \\
15 \mathrm{sec} \\
10 \mathrm{sec} \\
10 \mathrm{sec} \\
20 \mathrm{sec} \\
20 \mathrm{sec}\end{array}$ & $\begin{array}{l}3 \mathrm{~min} \\
3 \mathrm{~min} \\
2.5 \mathrm{~min} \\
1.5 \mathrm{~min} \\
2 \mathrm{~min} \\
1.5 \mathrm{~min} \\
2.5 \mathrm{~min} \\
2 \mathrm{~min} \\
6 \mathrm{~min}\end{array}$ & $\begin{array}{c}60-70 \% \text { of } \\
\text { maximum } \\
\text { strength }\end{array}$ \\
\hline & $\begin{array}{l}1 \text {.General and specific warming } \\
\text { up exercises walking, jogging, } \\
\text { running on spot with relaxation, } \\
\text { rotating activities and stationed } \\
\text { general and specific stretching } \\
\text { activities. } \\
\text { 2. Oblique } \\
\text { 3. Alternative crunch } \\
\text { 4.Bicycle } \\
\text { 5. Superman } \\
\text { 6.bird dog } \\
\text { 7.single plank } \\
\text { 8.single leg stabilizers } \\
\text { 9.outsiders } \\
\text { 10. Cooling down and stretching } \\
\text { activities }\end{array}$ & $\begin{array}{l}15 \\
15 \\
10 \\
10 \\
15 \\
- \\
\overline{15}\end{array}$ & $\begin{array}{l}4 \\
3 \\
3 \\
3 \\
4 \\
3 \\
3 \\
3 \\
3 \\
3\end{array}$ & $\begin{array}{l}- \\
- \\
- \\
- \\
\overline{2} 0 \mathrm{sec} \\
25 \mathrm{sec} \\
-\end{array}$ & $\begin{array}{l}15 \mathrm{sec} \\
15 \mathrm{sec} \\
15 \mathrm{sec} \\
15 \mathrm{sec} \\
15 \mathrm{sec} \\
10 \mathrm{sec} \\
10 \mathrm{sec} \\
20 \mathrm{sec}\end{array}$ & $\begin{array}{l}3 \mathrm{~min} \\
3 \mathrm{~min} \\
2.5 \mathrm{~min} \\
1.5 \mathrm{~min} \\
2 \mathrm{~min} \\
1.5 \mathrm{~min} \\
2.5 \mathrm{~min} \\
3 \mathrm{~min} \\
6 \mathrm{~min}\end{array}$ & $\begin{array}{c}70-90 \% \text { of } \\
\text { maximum } \\
\text { strength }\end{array}$ \\
\hline
\end{tabular}


Table: 12. Third Month Training Schedule (March, 2019)

\begin{tabular}{|c|c|c|c|c|c|c|c|}
\hline \multirow{2}{*}{$\begin{array}{l}\text { Days } \\
\text { per a } \\
\text { week }\end{array}$} & \multirow[t]{2}{*}{ Types of Exercises } & \multicolumn{5}{|c|}{ Time } & \multirow[t]{2}{*}{ Intensity } \\
\hline & & $\begin{array}{l}\text { No. } \\
\text { rep }\end{array}$ & $\begin{array}{l}\text { No. } \\
\text { set }\end{array}$ & $\begin{array}{l}\text { time } \\
\text { in } \\
\text { each } \\
\text { sets }\end{array}$ & $\begin{array}{l}\text { Recover } \\
\text { time }\end{array}$ & $\begin{array}{l}\text { Total } \\
\text { time(30- } \\
\text { 35min) }\end{array}$ & \\
\hline $\begin{array}{l}\text { Mond } \\
\text { ay } \\
5: 00- \\
5: 40 \\
\text { PM }\end{array}$ & $\begin{array}{l}1 \text {.General and specific warming up } \\
\text { exercises walking, jogging, } \\
\text { running on spot with relaxation, } \\
\text { rotating activities and stationed } \\
\text { general and specific stretching } \\
\text { activities. } \\
\text { 1.side bend } \\
\text { 2. reverse plank with leg raise } \\
\text { 3.squat } \\
\text { 4.situps } \\
\text { 5.six inch } \\
\text { 6. Russian twist } \\
\text { 7.leg and hip raiser } \\
\text { 8. Cool down breathing, stretching } \\
\text { exercises. }\end{array}$ & $\begin{array}{c}- \\
8 \\
8 \\
10 \\
\overline{10} \\
10\end{array}$ & $\begin{array}{l}3 \\
3 \\
3 \\
3 \\
3 \\
3 \\
4 \\
4\end{array}$ & $\begin{array}{l}30 \mathrm{sec} \\
- \\
- \\
\overline{15} \mathrm{sec} \\
- \\
-\end{array}$ & $\begin{array}{l}20 \mathrm{sec} \\
15 \mathrm{sec} \\
15 \mathrm{sec} \\
15 \mathrm{sec} \\
20 \mathrm{sec} \\
20 \mathrm{sec} \\
20 \mathrm{sec}\end{array}$ & $\begin{array}{l}10 \mathrm{~min} \\
3 \mathrm{~min} \\
3 \mathrm{~min} \\
3 \mathrm{~min} \\
3 \mathrm{~min} \\
3 \mathrm{~min} \\
3 \mathrm{~min} \\
4 \mathrm{~min} \\
5 \mathrm{~min}\end{array}$ & $\begin{array}{c}70-90 \% \text { of } \\
\text { maximum } \\
\text { strength }\end{array}$ \\
\hline $\begin{array}{l}\text { Wedns } \\
\text { day5:0 } \\
\text { 0-5:40 } \\
\text { PM }\end{array}$ & $\begin{array}{l}\text { 1. Warming up by } 3 \text { Vs } 3 \text { ball game } \\
\text { and specific warming up running } \\
\text { on spot with relaxation, rotating } \\
\text { activities and stationed general and } \\
\text { specific stretching activities. } \\
\text { 2. Crunches } \\
\text { 3. Reverse crunches } \\
\text { 4. Hip raiser } \\
\text { 5.the L sit } \\
\text { 6.pushup to side plank } \\
\text { 7.flutter kick } \\
\text { 8.russian twist } \\
\text { 9.single climbers } \\
\text { 10.cooling down and stretching } \\
\text { exercises }\end{array}$ & $\begin{array}{c}10 \\
15 \\
10 \\
8 \\
8 \\
\overline{10} \\
10\end{array}$ & $\begin{array}{l}4 \\
4 \\
3 \\
-4 \\
4 \\
3 \\
4\end{array}$ & $\begin{array}{l}- \\
- \\
- \\
10 \mathrm{sec} \\
\overline{15} \mathrm{sec} \\
- \\
-\end{array}$ & $\begin{array}{l}15 \mathrm{sec} \\
20 \mathrm{sec} \\
20 \mathrm{sec} \\
15 \mathrm{sec} \\
10 \mathrm{sec} \\
10 \mathrm{sec} \\
20 \mathrm{sec} \\
20 \mathrm{sec}\end{array}$ & $\begin{array}{l}10 \mathrm{~min} \\
\\
3 \mathrm{~min} \\
3 \mathrm{~min} \\
2.5 \mathrm{~min} \\
1.5 \mathrm{~min} \\
2 \mathrm{~min} \\
1.5 \mathrm{~min} \\
2.5 \mathrm{~min} \\
2 \mathrm{~min} \\
6 \mathrm{~min}\end{array}$ & $\begin{array}{c}70-90 \% \text { of } \\
\text { maximum } \\
\text { strength }\end{array}$ \\
\hline $\begin{array}{l}\text { Friday } \\
\text { at } \\
7: 00- \\
7: 40 \\
\text { AM }\end{array}$ & $\begin{array}{l}1 \text {.General and specific warming up } \\
\text { exercises walking, jogging, } \\
\text { running on spot with relaxation, } \\
\text { rotating activities and stationed } \\
\text { general and specific stretching } \\
\text { activities. } \\
\text { 2. Oblique } \\
\text { 3. Alternative crunch } \\
\text { 4.Bicycle } \\
\text { 5. Superman } \\
\text { 6.bird dog } \\
\text { 7.single plank } \\
\text { 8.single leg stabilizers } \\
\text { 9.outsiders } \\
\text { 10. Cooling down and stretching } \\
\text { activities }\end{array}$ & $\begin{array}{l}10 \\
10 \\
8 \\
8 \\
10 \\
- \\
\overline{10}\end{array}$ & $\begin{array}{l}4 \\
3 \\
3 \\
4 \\
5 \\
3 \\
4 \\
3\end{array}$ & $\begin{array}{l}- \\
- \\
- \\
- \\
\overline{2} 0 \mathrm{sec} \\
25 \mathrm{sec} \\
-\end{array}$ & $\begin{array}{l}10 \mathrm{sec} \\
15 \mathrm{sec} \\
15 \mathrm{sec} \\
10 \mathrm{sec} \\
15 \mathrm{sec} \\
10 \mathrm{sec} \\
10 \mathrm{sec} \\
20 \mathrm{sec}\end{array}$ & $\begin{array}{l}3 \mathrm{~min} \\
3 \mathrm{~min} \\
3 \mathrm{~min} \\
3 \mathrm{~min} \\
3 \mathrm{~min} \\
3 \mathrm{~min} \\
3.5 \mathrm{~min} \\
3 \mathrm{~min} \\
6 \mathrm{~min}\end{array}$ & $\begin{array}{c}70-90 \% \text { of } \\
\text { maximum } \\
\text { strength }\end{array}$ \\
\hline
\end{tabular}


Appendix-E

Table: 13. List of Subjects Participated in the Study

\begin{tabular}{|l|l|l|l|}
\hline No & Serial code of subjects & Weight $(\mathrm{Kg})$ & Height $(\mathrm{m})$ \\
\hline 1 & EG-1 & .72 & 61 \\
\hline 2 & EG-2 & 1.65 & 58 \\
\hline 3 & EG-3 & 1.71 & 58 \\
\hline 4 & EG-4 & 1.73 & 53 \\
\hline 5 & EG-5 & 1.70 & 63 \\
\hline 6 & EG-6 & 1.71 & 55 \\
\hline 7 & EG-7 & 1.71 & 58 \\
\hline 8 & EG-8 & 1.62 & 50 \\
\hline 9 & EG-9 & 1.65 & 65 \\
\hline 10 & EG-10 & 1.66 & 50 \\
\hline 11 & EG-11 & 1.65 & 51 \\
\hline 12 & EG-12 & 1.64 & 60 \\
\hline 13 & EG-13 & 1.65 & 50 \\
\hline 14 & CG-1 & 1.70 & 63 \\
\hline 15 & CG-2 & 1.77 & 65 \\
\hline 16 & CG-3 & 1.69 & 56 \\
\hline 17 & CG-4 & 1.67 & 51 \\
\hline 18 & CG-5 & 1.72 & 59 \\
\hline 19 & CG-6 & 1.80 & 67 \\
\hline 20 & CG-7 & 1.73 & 62 \\
\hline 21 & CG-8 & 1.72 & 59 \\
\hline 22 & CG-9 & 1.62 & 52 \\
\hline 23 & CG-10 & 1.76 & 60 \\
\hline 24 & CG-11 & 1.65 & 54 \\
\hline 25 & CG-12 & 1.70 & 62 \\
\hline 26 & CG-13 & 1.77 & \\
\hline & & & \\
\hline
\end{tabular}

\section{APPENDIX:F}

Table: 14. Pre, during and post raw data of agility tests (Illinois agility and $T$ test)

\begin{tabular}{|c|c|c|c|c|c|c|c|}
\hline NO. & Code/Name & pre-IAT & During-IAT & post-IAT & pre-TT & During TT & post- TT \\
\hline 1 & EG1 & 19.11 & 18.35 & 18.18 & 11.54 & 11.37 & 10.58 \\
\hline 2 & EG2 & 18 & 17.89 & 17.7 & 11.82 & 11.73 & 10.98 \\
\hline 3 & EG3 & 18.08 & 18.09 & 18 & 11.2 & 11.00 & 10.64 \\
\hline 4 & EG4 & 17.32 & 17.21 & 17.13 & 11.03 & 10.65 & 10.43 \\
\hline 5 & EG5 & 17.18 & 17.20 & 17.21 & 11.5 & 11.23 & 10.77 \\
\hline 6 & EG6 & 17.79 & 17.69 & 17.33 & 11.46 & 11.32 & 10.63 \\
\hline 7 & EG7 & 17.77 & 17.65 & 17.28 & 10.67 & 10.60 & 10.22 \\
\hline 8 & EG8 & 18.08 & 18.00 & 18.03 & 11.64 & 11.47 & 11 \\
\hline 9 & EG9 & 18.14 & 17.94 & 17.44 & 12.22 & 11.98 & 10.56 \\
\hline 10 & EG10 & 17.82 & 17.75 & 16.89 & 10.56 & 10.49 & 10.3 \\
\hline 11 & EG11 & 16.69 & 16.40 & 16.23 & 10.9 & 10.73 & 10.22 \\
\hline 12 & EG12 & 17.79 & 17.71 & 17.43 & 11.6 & 11.51 & 11.14 \\
\hline 13 & EG13 & 18.1 & 18.05 & 18.06 & 11.7 & 11.62 & 10.77 \\
\hline 14 & CG1 & 17.71 & 17.65 & 17.16 & 11.03 & 11.24 & 11.3 \\
\hline 15 & CG2 & 17.39 & 17.30 & 17.12 & 11.32 & 11.21 & 10.98 \\
\hline 16 & CG3 & 18.61 & 17.80 & 17.44 & 11.4 & 11.34 & 11 \\
\hline 17 & CG4 & 17.5 & 17.46 & 17.67 & 11.35 & 11.32 & 11.41 \\
\hline 18 & CG5 & 17.92 & 17.83 & 17.21 & 11.39 & 11.16 & 10.78 \\
\hline 19 & CG6 & 17.1 & 17.08 & 17.24 & 11.59 & 11.47 & 10.93 \\
\hline 20 & CG7 & 16.26 & 16.33 & 16.49 & 12.1 & 11.60 & 11.04 \\
\hline 21 & CG8 & 17.68 & 17.72 & 17.6 & 11.75 & 11.77 & 11.72 \\
\hline 22 & CG9 & 18.1 & 18.07 & 18.01 & 12.1 & 11.67 & 11.1 \\
\hline 23 & CG10 & 17.62 & 17.32 & 16.78 & 10.69 & 10.57 & 10.15 \\
\hline
\end{tabular}




\begin{tabular}{|r|l|r|r|r|r|r|r|}
\hline NO. & Code/Name & pre-IAT & During-IAT & post-IAT & pre-TT & \multicolumn{1}{l|}{ During TT } & post- TT \\
\hline 24 & CG11 & 17.84 & 17.81 & 17.72 & 10.83 & 10.80 & 10.71 \\
\hline 25 & CG12 & 18.93 & 18.89 & 17.79 & 11.78 & 11.76 & 11.68 \\
\hline 26 & CG13 & 19.1 & 19.00 & 18.74 & 12.2 & 12.09 & 11.83 \\
\hline
\end{tabular}

APPENDIX: G

Table: 15. Pre, during and post raw data of power tests (VJT\&SLJT)

\begin{tabular}{|c|c|c|c|c|c|c|c|}
\hline No. & Code/name & Pre-VJT & During VJT & Post-VJT & Pre-SLJT & DT of SLJT & Post-SLJT \\
\hline 1 & EG1 & 0.82 & .81 & 0.88 & 2.12 & 2.13 & 2.15 \\
\hline 2 & EG2 & 0.84 & .84 & 0.82 & 2.1 & 2.17 & 2.26 \\
\hline 3 & EG3 & 0.78 & .80 & 0.9 & 1.99 & 2.04 & 2.27 \\
\hline 4 & EG4 & 0.86 & .87 & 0.89 & 2.18 & 2.24 & 2.35 \\
\hline 5 & EG5 & 0.83 & .85 & 0.87 & 2.21 & 2.25 & 2.37 \\
\hline 6 & EG6 & 0.79 & .79 & 0.81 & 1.82 & 1.85 & 2.14 \\
\hline 7 & EG7 & 0.87 & .89 & 0.91 & 2.22 & 2.23 & 2.3 \\
\hline 8 & EG8 & 0.78 & .81 & 0.89 & 2.02 & 2.05 & 2.14 \\
\hline 9 & EG9 & 0.85 & .85 & 0.89 & 2.17 & 2.19 & 2.26 \\
\hline 10 & EG10 & 0.8 & .82 & 0.9 & 2.11 & 2.13 & 2.27 \\
\hline 11 & EG11 & 0.83 & .86 & 0.93 & 2.2 & 2.20 & 2.21 \\
\hline 12 & EG12 & 0.82 & .83 & 0.88 & 2.25 & 2.20 & 2.18 \\
\hline 13 & EG13 & 0.85 & .86 & 0.92 & 2.37 & 2.35 & 2.37 \\
\hline 14 & CG1 & 0.8 & .81 & 0.83 & 2.25 & 2.26 & 2.28 \\
\hline 15 & CG2 & 0.91 & .92 & 0.95 & 2.29 & 2.29 & 2.31 \\
\hline 16 & CG3 & 0.78 & .80 & 0.79 & 2.05 & 2.04 & 2.07 \\
\hline 17 & CG4 & 0.81 & .81 & 0.82 & 1.9 & 1.92 & 1.92 \\
\hline 18 & CG5 & 0.81 & .80 & 0.83 & 2.17 & 2.19 & 2.21 \\
\hline 19 & CG6 & 0.83 & .84 & 0.84 & 2.21 & 2.20 & 2.24 \\
\hline 20 & CG7 & 0.75 & .80 & 0.89 & 2.09 & 2.09 & 2.12 \\
\hline 21 & CG8 & 0.83 & .85 & 0.87 & 1.86 & 1.83 & 1.82 \\
\hline 22 & CG9 & 0.77 & .77 & 0.79 & 2.11 & 2.11 & 2.08 \\
\hline 23 & CG10 & 0.9 & .89 & 0.93 & 2.21 & 2.20 & 2.23 \\
\hline 24 & CG11 & 0.86 & .83 & 0.84 & 2.04 & 2.08 & 2.22 \\
\hline 25 & CG12 & 0.77 & .77 & 0.75 & 1.99 & 2.01 & 2.03 \\
\hline 26 & CG13 & 0.78 & .79 & 0.8 & 1.97 & 1.98 & 2.01 \\
\hline
\end{tabular}

\section{APPENDIX:H}

Table: 16.Pre, during and post raw data of speed tests (ST1\&ST2)

\begin{tabular}{|c|c|c|c|c|c|c|c|}
\hline No & S.C & pre-ST1 & During ST1 & post-ST1 & pre-ST2 & During ST2 & post-ST2 \\
\hline 1 & EG1 & 1.65 & 1.67 & 1.7 & 7.47 & 7.40 & 7.54 \\
\hline 2 & EG2 & 1.85 & 1.84 & 1.81 & 7.71 & 7.68 & 7.62 \\
\hline 3 & EG3 & 1.73 & 1.72 & 1.75 & 7.26 & 7.43 & 7.37 \\
\hline 4 & EG4 & 1.78 & 1.77 & 1.74 & 7.41 & 7.38 & 7.33 \\
\hline 5 & EG5 & 1.93 & 1.91 & 1.89 & 7.93 & 7.91 & 7.82 \\
\hline 6 & EG6 & 1.86 & 1.86 & 1.83 & 7.87 & 7.83 & 7.69 \\
\hline 7 & EG7 & 1.99 & 1.95 & 1.7 & 7.73 & 7.71 & 7.43 \\
\hline 8 & EG8 & 2.02 & 1.99 & 1.92 & 7.84 & 7.80 & 7.74 \\
\hline 9 & EG9 & 2.11 & 2.00 & 1.65 & 7.94 & 7.46 & 7.36 \\
\hline 10 & EG10 & 1.65 & 1.62 & 1.5 & 7.05 & 7.00 & 6.87 \\
\hline 11 & EG11 & 1.86 & 1.81 & 1.57 & 7.5 & 7.22 & 6.93 \\
\hline 12 & EG12 & 1.9 & 1.87 & 1.64 & 7.61 & 7.43 & 7.11 \\
\hline 13 & EG13 & 1.98 & 1.93 & 1.8 & 7.48 & 7.41 & 7.31 \\
\hline 14 & CG1 & 2.24 & 2.11 & 1.7 & 7.59 & 7.55 & 7.44 \\
\hline 15 & CG2 & 1.63 & 1.69 & 1.67 & 6.87 & 6.89 & 6.91 \\
\hline 16 & CG3 & 1.95 & 1.99 & 1.93 & 7.6 & 7.58 & 7.47 \\
\hline 17 & CG4 & 1.77 & 1.81 & 1.82 & 7.5 & 7.55 & 7.63 \\
\hline 18 & CG5 & 2 & 1.95 & 1.72 & 7.28 & 7.23 & 7.11 \\
\hline 19 & CG6 & 2.11 & 2.00 & 2.06 & 7.49 & 7.45 & 7.35 \\
\hline
\end{tabular}




\begin{tabular}{|r|l|r|r|r|r|r|r|}
\hline No & S.C & pre-ST1 & \multicolumn{1}{|c|}{ During ST1 } & post-ST1 & pre-ST2 & During ST2 & post-ST2 \\
\hline 20 & CG7 & 2.03 & 1.89 & 1.55 & 7.23 & 7.08 & 6.71 \\
\hline 21 & CG8 & 1.95 & 1.93 & 1.88 & 7.5 & 7.44 & 7.41 \\
\hline 22 & CG9 & 1.8 & 1.77 & 1.76 & 7.4 & 7.37 & 7.32 \\
\hline 23 & CG10 & 1.96 & 1.92 & 1.83 & 7.67 & 7.61 & 7.43 \\
\hline 24 & CG11 & 2.2 & 2.18 & 2.13 & 8.11 & 8.03 & 7.91 \\
\hline 25 & CG12 & 2.23 & 2.23 & 2.15 & 8.23 & 8.18 & 8.17 \\
\hline 26 & CG13 & 2.1 & 2.08 & 2.03 & 7.95 & 7.92 & 7.88 \\
\hline
\end{tabular}

